\title{
Visual Inspection Test with Acetic Acid for Cervical Cancer Screening: Willingness and Acceptability among Reproductive Age and Married Women
}

\author{
Rozaliamisah Binti Hassan, ${ }^{1}$ Edwin Armawan, ${ }^{2}$ Insi Farisa Desy Arya ${ }^{3}$ \\ ${ }^{1}$ Faculty of Medicine Universitas Padjadjaran, Indonesia, ${ }^{2}$ Department of Obstetric and \\ Gynecology Faculty of Medicine Universitas Padjadjaran/Dr. Hasan Sadikin General Hospital \\ Bandung, Indonesia, ${ }^{3}$ Department of Public Health Faculty of Medicine Universitas Padjadjaran, \\ Indonesia
}

\section{Abstract}

Background: Cervical cancer is a preventable disease, thus early screening test should be performed for early cervical cancer prevention. Previous studies showed that among all of the screening techniques, visual inspection with acetic acid is an alternative, simple safe cervical cancer prevention technique. This study aimed to identify the willingness and acceptability of visual inspection with acetic acid among reproductive age and married women as cervical cancer prevention.

Methods: A descriptive cross-sectional study was conducted among 100 reproductive age and married women in Jatinangor subdistrict West Java in 2014. A validated questionnaire was used to obtain information about the respondents's characteristics, risk factors of cervical cancer, willingness and acceptability of Visual Inspection using Acetic Acid Test (VIA). The collected data were presented using tables.

Results: Out of 100 respondents, 93\% ever heard of cervical cancer, however 79\% were aware of cervical cancer. As high as $96 \%$ were aware of the importance of cervical cancer screening, however $36 \%$ were aware of cervical cancer screening, and 19\% were aware of VIA test. While $83 \%$ never had previous education on cervical cancer, $91 \%$ reported willingness to take part on cervical cancer education and $83 \%$ willingness of cervical cancer screening. Noted $17 \%$ were non-acceptance of VIA test for future cervical cancer screening due to their busy life and afraid of the outcome result.

Conclusions: The majority of reproductive age and married women are willing and accept VIA test for cervical cancer screening.

Keywords: Acceptability, cervical cancer, visual inspection with acetic acid, willingness

\section{Introduction}

Cervical cancer is a major public health problem and become the second most common cancer in women worldwide. ${ }^{1,2}$ In Indonesia, the data from thirteen pathology centers show that cervical cancer stands the first-ranked among all cancers followed by cancers of the ovary, uterus, vulva, and vagina. ${ }^{3}$ Human papillomavirus(HPV) is the primary cause of infection with high-risk genotypes of human invasive cervical cancer; over $70 \%$ of all cervical cancers are attributable to infection with HPV-16 and 18.,5 The associated risk factors include young age at first intercourse less than 16 years, multiple sexual partners, cigarette smoking, race, high parity, and lower socioeconomic status. ${ }^{6}$ Undoubtedly, In Kecamatan Jatinangor, one of the densely populated areas in West Java ${ }^{7}$, there is still no other exact evidence for this study to state on the real cervical cancer statistics among women of reproductive age.

Due to the high prevalence of cervical cancer, screening testing is the most important test for early detection of the cancer. Various tests have been developed. Visual inspection using acetic acid (VIA test) emerges as a low-cost test for use in low-resource settings where it can be performed by auxiliary health professionals. ${ }^{8}$ Therefore, the objectives of this study were to identify the willingness and acceptability of VIA test among reproductive age and married women in Jatinangor area. 
Rozaliamisah Binti Hassan, Edwin Armawan, Insi Farisa Desy Arya: Visual Inspection Test with Acetic Acid 99 for Cervical Cancer Screening: Willingness and Acceptability among Reproductive Age and Married Women

\section{Methods}

This study was a descriptive cross-sectional study using questionnaires, with samples selected by simple random sampling. and was conducted from September-November 2014. This study was approved by the Health Research Ethics Committee Faculty of Medicine
Universitas Padjadjaran and Kabupaten Sumedang Official of the Local Development and Planning Office (BadanPerencanaan Pembangunan Daerah, BAPPEDA). Written informed consent was obtained from all women, prior to the interview.

One hundred married, reproductive age and literate women were included as respondents for this study. The validation and reliability

Table 1 Distribution of General Characteristics of Respondents, Kecamatan Jatinangor year $2014(n=100)$

\begin{tabular}{|c|c|c|}
\hline Characteristics & Frequency (Total, $n=100$ ) & Percentage (\%) \\
\hline \multicolumn{3}{|l|}{ Age } \\
\hline$<20$ years old & 2 & 2 \\
\hline 20-30 years old & 59 & 59 \\
\hline $30-40$ years old & 27 & 27 \\
\hline$>40$ years old & 12 & 12 \\
\hline \multicolumn{3}{|l|}{ Ethnicity } \\
\hline Sundanese & 97 & 97 \\
\hline Javanese & 2 & 2 \\
\hline Others & 1 & 1 \\
\hline \multicolumn{3}{|l|}{ Marital status } \\
\hline Married & 98 & 98 \\
\hline Widowed & 2 & 2 \\
\hline \multicolumn{3}{|l|}{ Educational level } \\
\hline Primary & 15 & 15 \\
\hline Secondary & 39 & 39 \\
\hline Tertiary & 46 & 46 \\
\hline \multicolumn{3}{|l|}{ Occupation } \\
\hline Yes & 83 & 83 \\
\hline No & 17 & 17 \\
\hline \multicolumn{3}{|l|}{ Salary per month } \\
\hline$<$ Rp 1 million/ month & 65 & 65 \\
\hline Rp 1-5 million/ month & 27 & 27 \\
\hline$>$ Rp 5 million/ month & 8 & 8 \\
\hline \multicolumn{3}{|l|}{ Husband's occupation } \\
\hline Yes & 97 & 97 \\
\hline No & 1 & 1 \\
\hline Others & 2 & 2 \\
\hline \multicolumn{3}{|l|}{ Husband's salary per month } \\
\hline$<$ Rp 1 million/ month & 26 & 26 \\
\hline Rp 1-5 million/ month & 50 & 50 \\
\hline$>$ Rp 5 million/ month & 22 & 22 \\
\hline Others & 2 & 2 \\
\hline
\end{tabular}


Table 2 Frequency of Reports of Known Risk Factors for Cervical Cancer among Study Respondent, Kecamatan Jatinangor, $2014(n=100)$

\begin{tabular}{|c|c|c|}
\hline Risk factors for cervical cancer & Frequency (Total, $n=100$ ) & Percentage $(\%)$ \\
\hline \multicolumn{3}{|l|}{ Age of marriage } \\
\hline$<20$ years old & 17 & 17 \\
\hline 20-30 years old & 83 & 83 \\
\hline 30-40 years old & 0 & 0 \\
\hline$>40$ years old & 0 & 0 \\
\hline \multicolumn{3}{|l|}{ Age at First Sexual Intercourse } \\
\hline$<20$ years old & 17 & 17 \\
\hline 20-30 years old & 83 & 83 \\
\hline 30-40 years old & 0 & 0 \\
\hline$>40$ years old & 0 & 0 \\
\hline \multicolumn{3}{|l|}{ Number of Lifetime Sexual Partner } \\
\hline 1 & 100 & 100 \\
\hline$>1$ & 0 & 0 \\
\hline \multicolumn{3}{|l|}{ Number of Living Children } \\
\hline 0 & 24 & 24 \\
\hline $1-2$ & 51 & 51 \\
\hline $3-4$ & 17 & 17 \\
\hline$\geq 5$ & 8 & 8 \\
\hline \multicolumn{3}{|l|}{ Smoking } \\
\hline Yes & 11 & 11 \\
\hline No & 89 & 89 \\
\hline \multicolumn{3}{|l|}{ Contraception use } \\
\hline Yes & 22 & 22 \\
\hline No & 78 & 78 \\
\hline
\end{tabular}

test for the questionnaire was performed on 29 respondents by using Cronbach's Alpha and if showed that the coefficient reliability was 0.706 were considered as reliable.

The target population included all selected reproductive age and married women in Kecamatan Jatinangor. It is noted that 19 is the minimum age to get married for male and 16 is the minimum age to get married for female in Indonesia.9As the theory of willingness is defined as an openness to risk opportunity, related to individual willingness to do under some circumstances.10 In this study, the willingness was measured by asking their willingness to take part in cervical cancer screening. Meanwhile, acceptability examines the relationships between beliefs, attitudes and behavior, which emphasizes the importance of understanding how judgments are made about whether or not to accept a proposition.10In this study, acceptability was measured by asking the respondents' acceptance of VIA test as cervical cancer screening in the future.

The respondents were asked about their characteristics (age, ethnicity, marital status, educational level, occupation, salary per month, husband's occupation and husband's salary per month). Risk factors contributed to the prevalence of cervical cancer were also identified (age of marriage, age at first sexual intercourse, number of lifetime sexual partners, number of living children, smoking and contraception use). The respondents were asked about their awareness of cervical cancer, willingness and acceptability of visual inspection with acetic acid as cervical cancer screening with a yes and no answer. The reasons for non-willingness and nonacceptance of visual inspection with acetic acid as cervical cancer screening were 
Rozaliamisah Binti Hassan, Edwin Armawan, Insi Farisa Desy Arya: Visual Inspection Test with Acetic Acid 101 for Cervical Cancer Screening: Willingness and Acceptability among Reproductive Age and Married Women

Table 3 Respondents' Awareness of Cervical Cancer, Kecamatan Jatinangor, $2014(\mathrm{n}=100)$

\begin{tabular}{|c|c|c|}
\hline Awareness of cervical cancer & Frequency (Total, $n=100$ ) & Percentage (\%) \\
\hline \multicolumn{3}{|l|}{ Aware of cervical cancer } \\
\hline Yes & 79 & 79 \\
\hline No & 21 & 21 \\
\hline \multicolumn{3}{|l|}{ Ever heard of cervical cancer } \\
\hline Yes & 93 & 93 \\
\hline No & 7 & 7 \\
\hline \multicolumn{3}{|l|}{ Aware of cervical cancer screening } \\
\hline Yes & 36 & 36 \\
\hline No & 64 & 64 \\
\hline \multicolumn{3}{|l|}{ Aware of importance for cervical cancer screening } \\
\hline Yes & 96 & 96 \\
\hline No & 4 & 4 \\
\hline \multicolumn{3}{|c|}{ Aware of Visual inspection using acetic acid (VIA test) } \\
\hline Yes & 19 & 19 \\
\hline No & 81 & 81 \\
\hline
\end{tabular}

included as well. Data from respondents were analyzed using a descriptive analysis and were presented using frequency distributions.

\section{Results}

This study revealed the majority of the respondents were between 20-30 years old
(59\%). Sundanese (97\%) was the predominant ethnicity of the respondents. Others (1\%) were meant for respondents whose ethnicity were not among both Sundanese and Javanese. Married women accounted for 98\%. There was low frequency of primary educational level (15\%).

It was noted, almost all respondents had

Table 4 Respondents' Willingness and Acceptability of Visual Inspection with Acetic Acid as Cervical Cancer Screening, Kecamatan Jatinangor, $2014(n=100)$

\begin{tabular}{|c|c|c|}
\hline & $\begin{array}{c}\text { Frequency, } \\
(\text { Total, } n=100)\end{array}$ & Percentage (\%) \\
\hline \multicolumn{3}{|c|}{ Previous information related to cervical cancer } \\
\hline Yes & 17 & 17 \\
\hline No & 83 & 83 \\
\hline \multicolumn{3}{|c|}{ Willingness to take part in cervical cancer information } \\
\hline Yes & 91 & 91 \\
\hline No & 9 & 9 \\
\hline \multicolumn{3}{|c|}{ Willingness to cervical cancer screening } \\
\hline Yes & 83 & 83 \\
\hline No & 17 & 17 \\
\hline \multicolumn{3}{|c|}{ Acceptance of VIA test as cervical cancer screening in the future } \\
\hline Yes & 83 & 83 \\
\hline No & 17 & 17 \\
\hline
\end{tabular}


an occupation (83\%) and a salary rate of less than Rp1 million per month (65\%). Still there were few of them whose salary were more than Rp 5 million per month (8\%). Husband's occupation had a high frequency (97\%) and husband'salary $\mathrm{p}$ was between Rp 1-5 million per month (50\%). Others (2\%) were meant for their deceased husband (Table 1).

Regarding risk factors contributed to the prevalence of cervical cancer, this study discovered that the age of marriage of less than 20 years accounted for $17 \%$ and the age of first sexual intercourse was at rate of $17 \%$. There was none with number of lifetime sexual partner of more than one. The number of living children was equal and more than 5 children accounted the least for $8 \%$. It noted low frequency among smoking respondents as $11 \%$ and as low as $22 \%$ of them used contraception (Table 2).

Furthermore, based on the respondents' awareness of cervical cancer, $79 \%$ of the respondents were aware of cervical cancer, as high as $93 \%$ ever heard of cervical cancer, and still about $7 \%$ never heard of cervical cancer. Even though only approximately $36 \%$ of them were aware of cervical cancer screening, about $96 \%$ of all respondents were aware of the importance for cervical cancer screening. A substantial 19\% of the respondents were aware of VIA test (Table 3).

This study discoveref that $83 \%$ of the respondents never had previous information on cervical cancer. As high as $91 \%$ of them were willing to take part in cervical cancer education and $83 \%$ of the respondents were willing to be screened for cervical cancer. Overall, there was a high rate of acceptance for VIA test as cervical cancer screening in the future $(83 \%)$.

Reasons for non-acceptance of VIA test as cervical cancer screening in the future have been written by the respondents via the questionnaires. Of 100 respondents who took part in this study, $83 \%$ of respondents accepted the IVA test as cervical cancer screening in the future, and as low as $17 \%$ of respondents rejected it. The majority of respondents' non-acceptance of VIA test as cervical cancer screening in the future were due to their fear of knowing the results and because they were busy.

\section{Discussions}

The study provided information about willingness and acceptability of visual inspection with acetic acid as cervical cancer screening among reproductive age and married women in Kecamatan Jatinangor in 2014. Overall, there were positive outcomes from this study. The majority of respondents were between the ages of 20-30 (59\%) which indicated early marriage among them. The Sundanese was the highest frequency distribution of ethnicity with $97 \%$, only $2 \%$ of them were Javanese, and others were $1 \%$. Most of the women were married (98\%) and widowed $(2 \%)$ which meant their husbands had passed away. The educational level at highest frequency was the tertiary level (46\%), yet this did not always indicate high awareness of cervical cancer. However, a previous study showed that the awareness level would have been much higher if the respondents were among high education level. ${ }^{10}$ The study showed a high rate as $46 \%$ of the respondents were with tertiary education level, followed by the secondary level $(39 \%)$ and primary level $(15 \%)$.

Almost all of them had an occupation (83\%) and only $17 \%$ did not have an occupation and stayed as housewives. Overall, their salaries were less than Rp1 million per month (65\%) and were considered as low income status. In addition, almost all their husband had an occupation (97\%), only 1\% did not have an occupation, and others $(2 \%)$ indicated their deceased husband. Their husband's salary was between Rp1-5 million per month (50\%) which implied a low income status. However, this information did not always prove any relation to high or low willingness and acceptability of the study.

Moreover, the results showed the distribution related risk factors for cervical cancer were included. In worrisome states, there were about $17 \%$ of respondents at early age of marriage and meant for having early sexual intercourse simultaneously. The study found that these could contribute for the risk of cervical cancers. ${ }^{11}$ There were $100 \%$ of women with only 1 partner in a lifetime and this was somehow a relief for not being a risk for cervical cancer. However, the number of living children was equal and more than 5 children was $8 \%$ which proved to be a risk for cervical cancer. ${ }^{12}$ Fortunately, there were only a few women smoking $(11 \%)$ and only a few of them used contraception (22\%). Regarding the use of contraception, this variable could be considered as the risk factor for cervical cancer. $^{13}$

Additionally, the respondents' awareness of cervical cancer showed an interesting finding that there was still high awareness of cervical 
cancer $(79 \%)$ and a high rate for "ever heard of cervical cancer" (93\%). Surprisingly, only a few (36\%) among the respondents were aware of cervical cancer screening, and about $19 \%$ of them were aware of the VIA test. Quite a remarkable finding was that as high as $96 \%$ were aware of the importance for cervical cancer screening.

Furthermore, the frequency distribution demonstrated only $17 \%$ of women had previous education on cervical cancer, a previous study found this variable has a strong relation with the high outcome for the risk of cervical cancer. ${ }^{10}$ Interestingly, the willingness to take part in cervical cancer education was high at 91\% and $83 \%$ were willing to be screened for cervical cancer. Moreover, $83 \%$ of the respondents accepted VIA test as cervical cancer screening in the future. The respondents stated the reasons for non-acceptance of VIA test, and most of them wrote that their non-acceptance were due to their fear of the outcome result, besides they were busy. A previous study found that other reasons for non-acceptance of cervical cancer screening among the respondents include the cost of test related issues, religious denial, requires partners permission, time to take the test/long waiting time, pregnant/recently delivered, afraid to take the test, taken the test before, had surgery of the vulva and no reason. ${ }^{10}$

As for the limitation of study, the researcher did not measure unmarried and reproductive age women. This should be measured for more variation and clear data. Then, there was limited variation for ethnicity and religion and a limited list of variables for education level, as such, the data for illiterate respondents. Next, there was no list for types of occupation for the respondent's husband which was important for measuring the level of their socioeconomic status. Also, the variables were listed without the types of contraceptives. Hopefully, there will further studies on measuring association or correlation study regarding the cervical cancer prevention as part of health promotion. Besides, it is best to proceed on more interesting topic under cervical cancer study for on-going research.

In conclusion, the majority of reproductive age and married women in Kecamatan Jatinangor are willing and accepted VIA test for cervical cancer screening. The researcher discovers the need to educate reproductive age and married women in Kecamatan Jatinangor for cervical cancer prevention and demonstrates their willingness to be screened for cervical cancer and visual inspection with acetic acid would be acceptable as cervical cancer screening. Last but not least, the researcher includes recommendations throughout the study. Practically, education on cervical cancer should be organized as a part of on-going health education, so women can get access and implement visual inspection with acetic acid as cervical cancer screening in all health care centers, since it is the safest, cheapest and highly sensitive screening test for cervical cancer.

\section{References}

1. Kotaniemi-Talonen L, Malila N, Anttila $A$, Nieminen P, Hakama M. Intensified screening among high risk women within the organised screening programme for cervical cancer in Finland. Acta Oncol. 2011;50(1):106-11.

2. Vesco KK, Whitlock EP, Eder M, Burda BU, Senger CA, Lutz K. Risk factors and other epidemiologic considerations for cervical cancer screening: a narrative review for the U.S. Preventive Services Task Force. Ann Intern Med.2011;155(10):698-705.

3. Nuranna L, Aziz MF, Santoso Cornain, Gatot Purwoto, Sigit Purbadi, Setyawati Budiningsih, et al. Cervical cancer prevention program in Jakarta, Indonesia: See and Treat model in developing country. J Gynecol Oncol. 2012;23(3):147-52.

4. Bosch FX, Qiao YL, Castellsague' X. CHAPTER 2 The epidemiology of human papillomavirus infection and its association with cervical cancer. Int Jf Gynecol Obstet. 2006;94(Suppl 1):S8-S21.

5. Smith JS, Lindsay L, Hoots B, Keys J, Franceschi S, Winer R, et al. Human papillomavirus type distribution in invasive cervical cancer and high-grade cervical lesions: a meta-analysis update. Int J Cancer. 2007;121(3):621-32.

6. Harris RP, Helfand M, Woolf SH, Lohr KN, Mulrow CD, Teutsch SM, et al. Current methods of the US Preventive Services Task Force: a review of the process. Am J Prev Med. 2001;20(3 Suppl):21-35.

7. Kecamatan Jatinangor. Potensi Kecamatan Jatinangor Triwulan II Tahun 2009. Sumedang: Kecamatan Jatinangor; 2013.

8. International Agency for Research on Cancer. Cervix cancer screening: IARC Handbook of Cancer Prevention. 10th ed. Lyon, France: IARC Pr; 2005.

9. Kementerian Agama Republik Indonesia. Peraturan Menteri Agama Republik 
Indonesia Nomor 11 Tahun 2007 Tentang Pencatatan Nikah. Jakarta: Kementerian Agama Republik Indonesia; 2007.

10. Ezechi Oliver C, Gab-Okafor Chidinma V, Ostergren Olof Per, Pettersson Odberg. Willingness and acceptability of cervical cancer screening among HIV positive Nigerian women. BMC Public Health. 2013;13:46.

11. Rositch AF, Gatuguta A, Choi RY, Guthrie BL, Mackelprang RD, Bosire Rose, et al. Knowledge and acceptability of pap Smears, self-sampling and HPV vaccination among adult women in Kenya. PloS One. 2012;7(7):e40766.

12. Were E, Nyaberi Z, Buziba N. Perceptions of risk and barriers to cervical cancer screening at Moi Teaching and Referral Hospital (MTRH), Eldoret, Kenya. Afr Health Sci. 2011;11(1):58-64.

13. Nene B, Jayant K, Arrossi S, Shastri S, Budukh A, Hingmire, et al. Determinants of womens participation in cervical cancer screening trial, Maharshtra, India. Bull World Health Organ.2007;85(4):264-72. 